\title{
Studi Komparasi Kinerja Teknologi Near Field Communication Pada Sistem Berbasis Android dan Embedded System \author{
and Embedded based System
} \\ A study of comparation of Near Field Communication performance on Android based
}

\author{
Muhammad Haries, Yuwaldi Away, Fitri Arnia \\ Program Studi Magister Teknik Elektro, Universitas Syiah Kuala \\ E-mail: haries93@mhs.unsyiah.ac.id,yuwaldi@unsyiah.ac.id, f.arnia@unsyiah.ac.id.
}

\begin{abstract}
Abstrak
Penelitian ini membahas perbandingan kinerja dua perangkat berbasis Android dan Embedded system dalam melakukan pembacaan tag Near Field Communication. Perangkat berbasis Android menggunakan modul NFC NXP PN544 dan Embedded system menggunakan modul MFRC522. Studi kasus yang dilakukan untuk penelitian ini dengan menerapkannya pada manajemen aset. Penelitian ini bertujuan mengetahui kinerja dari kedua perangkat tersebut mana yang lebih cepat dalam membaca tag NFC berdasarkan waktu dan jarak, kemudian hasil data yang didapatkan akan diuji untuk melihat terdapat perbedaan signifikan atau tidak. Setelah dilakukan pengujian, jarak efektif pada kedua perangkat dimulai dari $15 \mathrm{~mm}$. Untuk sampel jarak yang digunakan adalah $15 \mathrm{~mm}, 10 \mathrm{~mm}$, dan $5 \mathrm{~mm}$ dengan pengujian pembacaan 15 tag NFC serta didapatkan hasil bahwa Android lebih cepat dibanding Embedded system dan hasil kedua perangkat terdapat perbedaan signifikan dalam melakukan pembacaan tag. Hasil data berdasarkan waktu dan jarak dari dua perangkat yang didapatkan diuji menggunakan metode statistik uji Mann Whitney. Dengan metode uji Mann Whitney tersebut, diketahui perbedaan signifikan dari kedua perangkat berdasarkan hasil yang didapatkan. Pada jarak $15 \mathrm{~mm}$ didapatkan nilai signifikasi sebesar .001 , kemudian pada jarak $10 \mathrm{~mm}$ didapatkan nilai signifikasi sebesar .000 , serta jarak $5 \mathrm{~mm}$ didapatkan nilai signifikasi sebesar .000 dan dari ketiga pengujian tersebut membuktikan bahwa kedua perangkat terdapat perbedaan signifikan dalam melakukan pembacaan tag NFC.
\end{abstract}

Kata kunci: Near Field Communication, NFC, Android, Embedded System, Aset.

\begin{abstract}
This study discusses the comparison of the performance of two Android-based devices and the embedded system in reading Near Field Communication tags. Those Android based use NFC module NXP PN544 and Embedded system use MFRC522 module. For this analysis, a case study was carried out using it for asset management. It will then test results of data obtained to determine whether there is a significant difference or not in the performance of both devices, which is fastest to read the NFC tags based on time and distance. After testing, the effective distance on both devices starts from $15 \mathrm{~mm}$. For the sample, the distances used were $15 \mathrm{~mm}, 10$ $\mathrm{mm}$, and $5 \mathrm{~mm}$ by reading $15 \mathrm{NFC}$ tags at each distance and the results showed that Android was faster than the Embedded system; the findings of the two devices were significant differences in tag reading. The findings were evaluated using a Mann Whitney predictive research system based on time and distance from the two devices collected. With the Mann Whitney test method, it is known that the significant differences between the two devices are based on the results obtained. A significance value of.001 is obtained at a distance of $15 \mathrm{~mm}$, followed by a significance value of.000 at a distance of $10 \mathrm{~mm}$, and a significance value of.000 at a distance of $5 \mathrm{~mm}$, proving that the two systems have major variations in reading NFC tags.
\end{abstract}

Keywords: Near Field Communication, NFC, Android, Embedded System, Asset. 


\section{PENDAHULUAN}

Teknologi Near Field Communication (NFC) sudah ditemukan. NFC digunakan sebagai standar komunikasi nirkabel jarak pendek dengan teknologi yang mengijinkan dua jalur komunikasi. Teknologi terbaru dari cara mengakses NFC tag adalah dengan menyelaraskan koneksi yang terpusat pada database / pangkalan data yang sudah divalidasi. Beberapa manfaat yang dimiliki oleh NFC ini relatif jika dibandingkan dengan teknologi seperti scanner optik (pemindai mata), pembaca sidik jari, dan penerapan level keamanan jika dibandingkan dengan pembaca barcode. Teknologi NFC kini diterapkan pada 2 sistem yaitu Android dan Embedded system.

Pada penelitian ini dilakukan pengujian pembacaan tag NFC untuk mengetahui kinerja dari kedua perangkat yaitu Android sistem dan Embedded system. Sehingga didapatkan mana perangkat yang lebih cepat. Kemudian melihat apakah terdapat perbedaan signifikan diantara dua perangkat tersebut dalam pembacaan tag NFC berdasarkan pada waktu serta jarak.

Studi kasus yang akan dilakukan adalah dengan menerapkannya pada manajemen aset. Manajemen aset akan sangat diperlukan pada instansi manapun untuk pendataan barang dan membutuhkan perangkat yang cepat untuk melakukan hal tersebut. Penerapan teknologi Near Field Communication ini dapat dilakukan untuk menyelesaikan tugas tersebut.

Kajian terkait yang berhubungan dengan manajemen aset berupa sistem manajemen aset untuk peralatan medis. Dimana penjaga peralatan dapat memonitor dan melacak peralatan medis menggunakan pembaca NFC untuk berkomunikasi dengan tag NFC yang dipasang pada perangkat medis [1]. Penelitian lain yaitu pengujian pembacaan tag NFC pada Android berupa sistem kontrol untuk mengakses ruangan sebagai alternatif ISO 14443A yang umumnya menggunakan Host Based Card Emulation pada modul Arduino NFC yang diimplementasikan pada Android dengan melakukan pengujian pembacaan tag NFC dengan berdasarkan jarak dan waktu [2]. Kemudian terdapat penelitian aplikasi Android untuk melakukan pembayaran belanja untuk mengurangi kontak fisik menggunakan NFC, menjelaskan tentang waktu rata-rata Android memproses pembacaan tag NFC [3]. Penelitian aplikasi penjualan tiket kereta api menggunakan NFC berbasis sistem Android untuk menggantikan sistem tiket kereta api manual menjadi $e$-ticket, yang juga menjelaskan salah satunya proses kecepatan pembacaan tag NFC [4]. Tujuan dari penelitian ini adalah mengetahui hasil komparasi kinerja dari kedua perangkat tersebut dalam membaca tag NFC berdasarkan waktu dan jarak, yang nantinya akan diterapkan pada manajemen aset. Kemudian hasil data pembacaan tag diuji untuk melihat apakah terdapat perbedaan signifikan atau tidak diantara kedua perangkat dalam melakukan pembacaan tag NFC.

\section{METODE PENELITIAN}

\subsection{Aplikasi Android dan Alat Embedded System}

Pada Android, modul NFC telah disematkan pada smartphone. Fungsi NFC sudah dikenalkan sejak perangkat Android 2.3 (API level 9), dan pada Android 2.3.3 (API level 10) kemampuan penulisan dan pertukaran data melalui mode Peer to Peer (P2P) mulai diterapkan [4]. Sistem operasi Android digunakan untuk menjalankan aplikasi secara multitasking / banyak aplikasi berjalan secara bersamaan [5]. Perangkat keras yang digunakan untuk melakukan pengujian aplikasi manajemen aset dan pembacaan tag NFC adalah Samsung J7 2016 dengan spesifikasi NXP PN544 dengan processor Exynos 7870 CPU 2.2GHz Octa-core, RAM 2 GB dan sistem operasi Android 8.1 Oreo. NXP PN544 juga digunakan pada HTC One [6]. Produsen peralatan seluler mengharapkan sistem operasi NFC (sistem operasi NFC) berdiri sendiri, peranti keras sendiri, dan kerangka kerja OS yang mampu beradaptasi. Usulan NFC runtime juga divalidasi oleh Android dan Windows Phone OS [7]. 


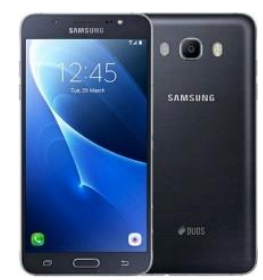

Gambar 1 Samsung j7 2016

Pada Embedded system, perangkat keras dirakit dan digabungkan sesuai dengan kebutuhan pengujian kinerja dalam pembacaan tag NFC yang kemudian diprogram untuk pembacaan tag NFC. Komponen utama yang digunakan adalah Arduino Mega 2560 dengan 54 pin digital I/O, kecepatan $16 \mathrm{MHz}$, DAN $256 \mathrm{~kb}$ memori [8,9]. Modul MFRC522 dengan standar ISO 14443 A untuk melakukan pembacaan tag NFC [10].

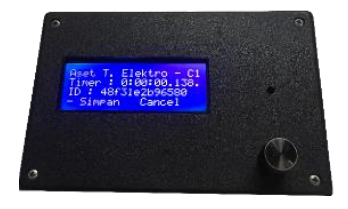

Gambar 2 Alat embedded system

\subsection{Perancangan Mengukur Jarak Antara Arduino, Android, dan Tag NFC.}

Pada penelitian ini juga dibutuhkan perancangan yang digunakan untuk mengukur jarak dari kedua alat yang akan melakukan pembacaan tag NFC. Rancangan pengukuran jarak ini dibuat menggunakan kayu sebagai alasnya dan alumunium sebagai tiang dengan tinggi $15 \mathrm{~cm}$ yang dilubangi (20 lubang vertikal dan 4 lubang horizontal) dengan selisih jarak tiap lubangnya adalah $5 \mathrm{~mm}$ (lubang dibuat hingga $100 \mathrm{~mm}$ ).

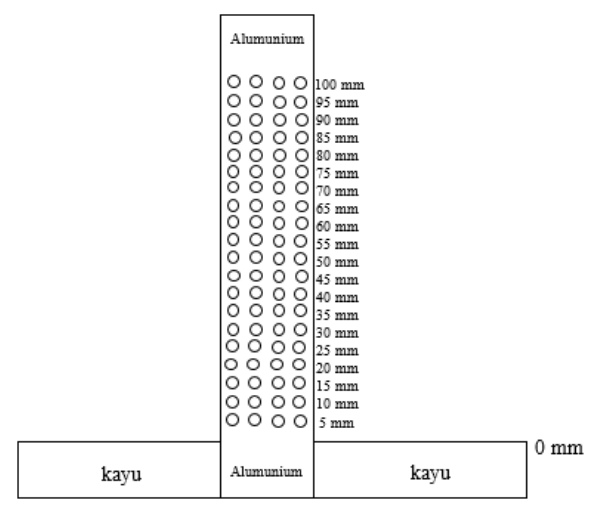

Gambar 3 Tampak samping untuk menghitung jarak

Tag NFC yang akan digunakan untuk pengujian pembacaan adalah Ultralight $C$ tag NFC koin tipe 2 berdasarkan ISO 14443A dengan memori dasar 48 byte dan kecepatan komunikasi 106 kbit/s [11]. Selanjutnya tag NFC akan diletakkan pada bagian alas kayu (pada titik $0 \mathrm{~mm}$ ) dan kemudian pada lubang tersebut dimasukkan besi panjang seperti pada panggangan sesuai dengan kebutuhan untuk menghitung jarak tag dari alat yang diinginkan. Bentuk panggangan seperti ini agar hambatan lebih sedikit dan gelombang radio tetap dapat menembus ke bagian bawah besi untuk dapat membaca tag. NFC merupakan subset dari RFID yang mana teknologi ini mampu menyederhanakan transaksi, pertukaran data, dan koneksi nirkabel antar dua perangkat komunikasi dengan jarak amat dekat (hanya beberapa sentimeter) dengan prinsip induksi medan magnetic [12]. Untuk pengujian jarak baca, besi dimasukkan sesuai dengan lubang yang telah dibuat sebelumnya. 


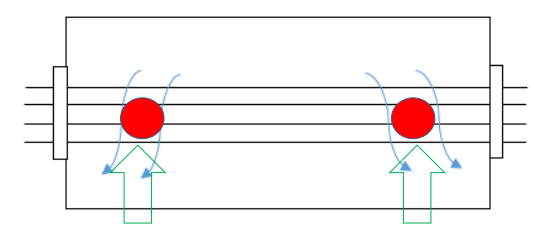

Gambar 4 Tampak atas untuk menghitung jarak

Kemudian kedua alat (Android dan Embedded system) diletakkan diatas besi panggangan. Alat harus berada dalam posisi read untuk dapat membaca tag NFC. Selanjutnya tag NFC dimasukkan ke bagian atas kayu (pada bagian bawah besi panggangan) secara bersamaan. Maka ketika tag NFC terdeteksi timer akan mulai berjalan pada masing-masing perangkat dan akan berhenti ketika informasi tag NFC muncul. Untuk perancangan dan penempatan alat dapat dilihat seperti pada gambar berikut :

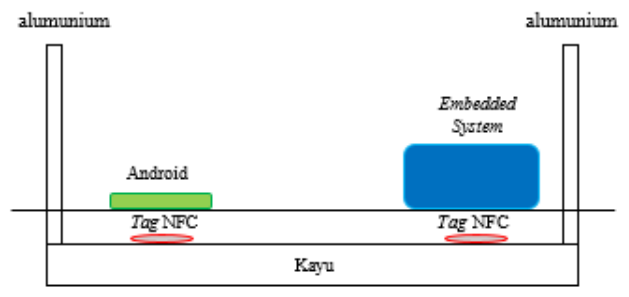

Gambar 5 Tampak alat untuk menghitung jarak baca tag NFC

\subsection{Penerapan Pada Manajemen Aset}

Penelitian ini nantinya akan diterapkan pada manajemen aset. Tag NFC akan ditempelkan pada setiap aset yang ingin didata seperti komputer, laptop, dan sebagainya. Untuk pendataan, perangkat akan membaca tag NFC yang sudah ditempelkan dan membaca informasi yang terdapat pada tag NFC tersebut. Informasi yang didapatkan selanjutnya disimpan kedalam tempat penyimpanan database MySQL. Hal ini akan dilakukan setelah diketahui perangkat mana yang lebih cepat dalam melakukan pembacaan tag NFC serta didapatkan hasil uji apakah terdapat perbedaan yang signifikan atau tidak diantara kedua perangkat.

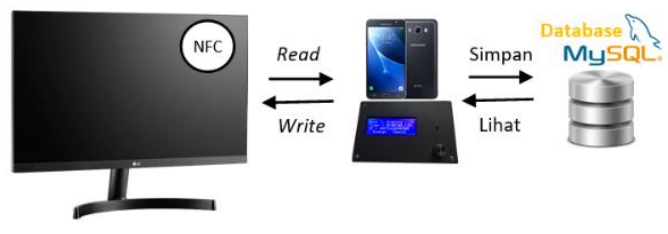

Gambar 6 Penandaan aset dan mekanisme kerja

\subsection{Perancangan Pembacaan dan Penyimpanan Informasi Tag NFC}

Perangkat Android dan Embedded system dirancang menggunakan alur program yang sama. Mekanisme kerja kedua perangkat ini diawali dengan penulisan informasi pada tag NFC. Kemudian dilakukan koneksi pada jaringan agar kedua perangkat dapat terhubung ke database MySQL. Yang harus dilakukan adalah mengecek SSID dan password pada jaringan apakah sudah benar. Jika sudah terkoneksi dengan jaringan namun tidak terkoneksi ke database maka selanjutnya melakukan pengecekan apakah database MySQL sudah berjalan dan apakah IPv4 server yang digunakan berada di kelas yang sama dengan perangkat yang terkoneksi.

Setelah terkoneksi dengan database MySQL, penyimpanan informasi waktu dan akses untuk melihat hasil pembacaan tag NFC dapat dilakukan. Kemudian tag NFC yang telah berisi informasi aset yang telah ditulis sebelumnya didekatkan pada smartphone dan alat Embedded yang kemudian akan membaca apakah tag NFC tersebut berhasil terdeteksi atau tidak. Jika ya, 
maka tahap selanjutnya timer akan mulai berjalan dan menghitung waktu dengan satuan milisecond. Ketika informasi dan tag id muncul maka secara otomatis timer akan berhenti dan menunjukkan waktu yang didapatkan. Waktu yang didapatkan adalah proses dari tag terdeteksi hingga informasi dari tag muncul. Hasil akhir yang didapatkan nantinya adalah informasi, id, serta waktu yang berada didalam tag tersebut yang dapat disimpan ke dalam database.

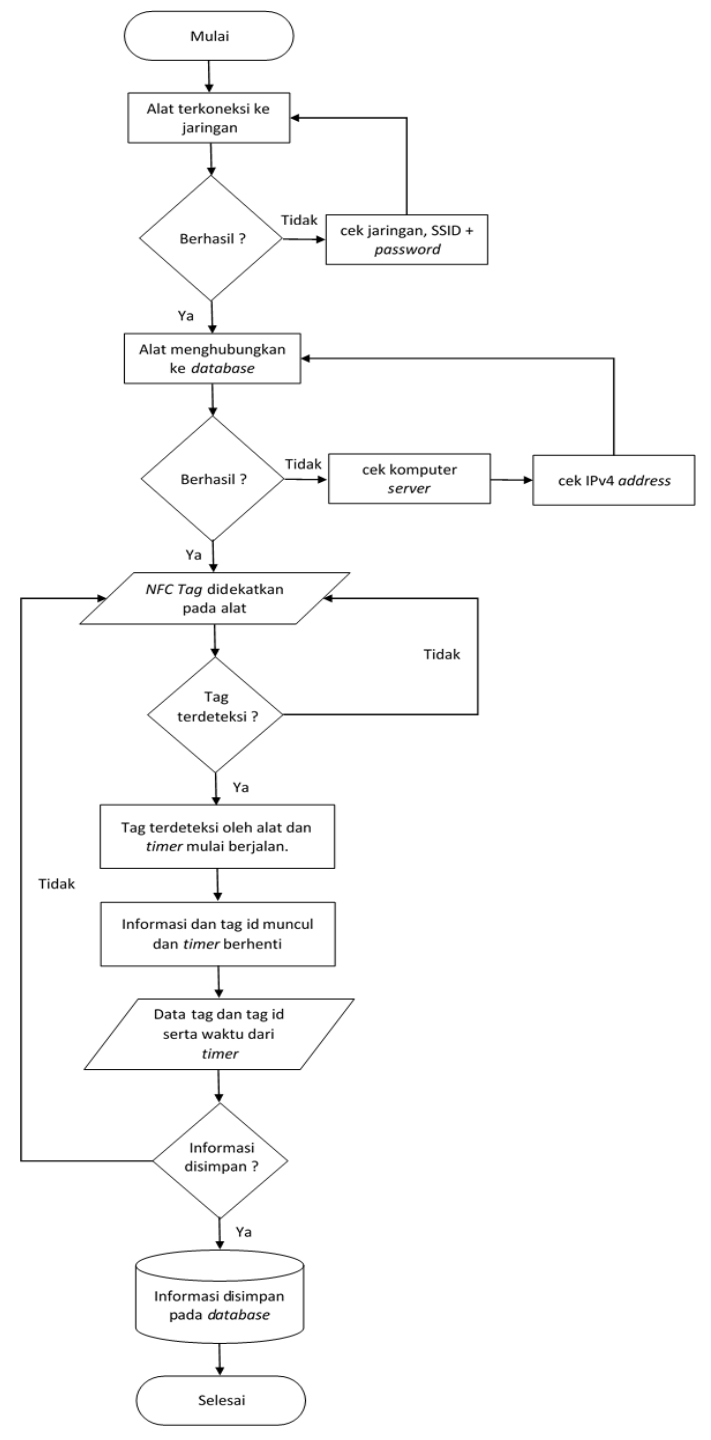

Gambar 7 Alur pembacaan tag NFC.

\subsection{Perhitungan Data Jarak dan Waktu}

Hasil pengujian waktu berdasarkan sampel jarak pada 15 tag yang telah dibaca oleh kedua perangkat selanjutnya diuji menggunakan metode statistik untuk melihat apakah hasil waktu dari kedua perangkat terdapat perbedaan atau tidak. Metode uji yang dipakai untuk menguji kebenaran atau kepalsuan hipotesis yang menyatakan bahwa diantara dua buah mean sample yang diambil secara random dari populasi yang sama tidak terdapat perbedaan signifikan adalah uji sample T-test dan uji Mann Whitney (uji U). Perbedaan dari kedua metode ini adalah syarat pada uji sample T-test hasil pengujian data sampel harus berdistribusi normal sedangkan pada uji Mann Whitney, hasil uji tidak harus berdistribusi normal [13,14]. 


\section{HASIL DAN PEMBAHASAN}

Hasil yang didapatkan setelah melakukan pengujian kinerja pembacaan tag NFC pada perangkat Android dan Embedded system diketahui jarak efektif kedua perangkat membaca tag NFC dimulai pada $15 \mathrm{~mm}$. Selanjutnya pengujian pembacaan tag NFC dilakukan dengan mengambil sampel pada jarak $15 \mathrm{~mm}, 10 \mathrm{~mm}$, dan $5 \mathrm{~mm}$ dengan melakukan pembacaan tag NFC pada setiap jarak sebanyak 15 tag.

Untuk pengujian pembacaan, kedua perangkat berada dalam mode read. Selanjutnya tag NFC dimasukkan secara bersamaan ke bagian atas kayu (dibawah besi panjang mirip panggangan). Maka ketika tag NFC terdeteksi timer akan mulai berjalan dan akan berhenti ketika informasi dari tag NFC muncul. Untuk penempatan dan pengujian alat dapat dilihat pada gambar berikut :

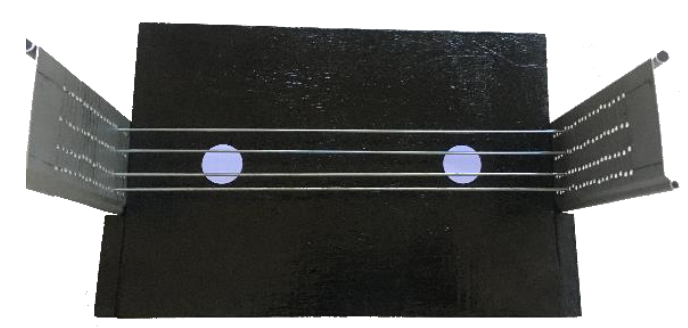

Gambar 8 Tampak atas tag NFC koin.

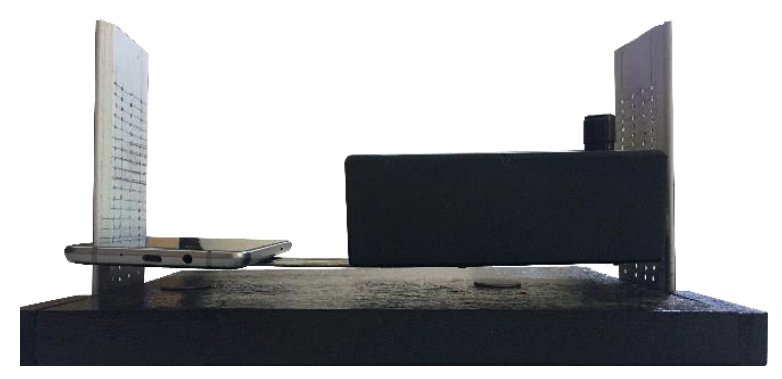

Gambar 9 Tampak kedua perangkat membaca tag NFC

Berikut ini adalah informasi waktu pada jarak $15 \mathrm{~mm}$ yang terbaca pada kedua perangkat (Android dan Embedded system) dapat dilihat pada Tabel 1.

Tabel 1 Pengujian pembacaan tag pada jarak $15 \mathrm{~mm}$

\begin{tabular}{|c|c|c|c|}
\hline $\begin{array}{c}\text { Jarak } \\
(\mathbf{m m})\end{array}$ & Tag & $\begin{array}{c}\text { Waktu } \\
\text { Android } \\
(\mathbf{m s})\end{array}$ & $\begin{array}{c}\text { Waktu } \\
\text { Embedded } \\
(\mathbf{m s})\end{array}$ \\
\hline 15 & 1 & - & 177 \\
\hline 15 & 2 & 28 & 176 \\
\hline 15 & 3 & - & 177 \\
\hline 15 & 4 & - & 177 \\
\hline 15 & 5 & - & 175 \\
\hline 15 & 6 & - & 176 \\
\hline 15 & 7 & 338 & 176 \\
\hline 15 & 8 & 29 & 176 \\
\hline 15 & 9 & - & 176 \\
\hline 15 & 10 & 29 & 175 \\
\hline 15 & 11 & 28 & 175 \\
\hline 15 & 12 & 29 & 175 \\
\hline 15 & 13 & 28 & 175 \\
\hline 15 & 14 & 28 & 175 \\
\hline 15 & 15 & 29 & 176 \\
\hline
\end{tabular}


Dari hasil pengujian pada tabel dapat dilihat melalui grafik pada Gambar 10.

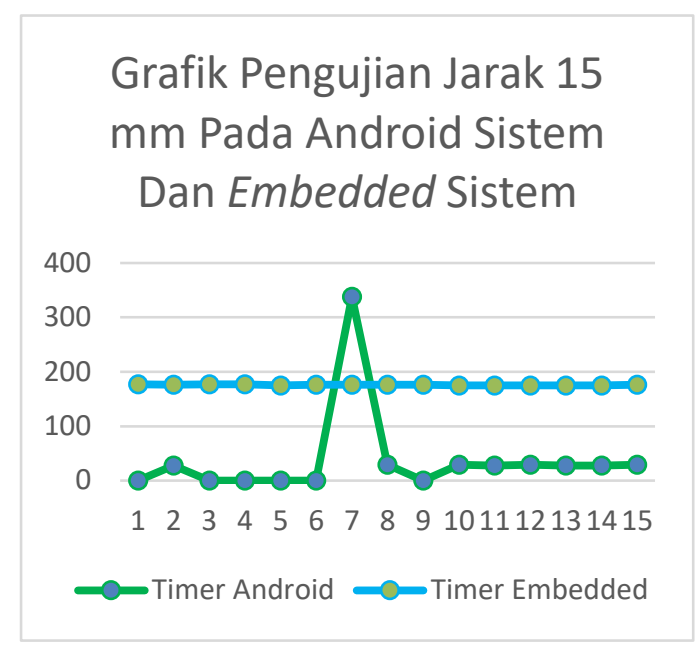

Gambar 10 Grafik pengujian jarak $15 \mathrm{~mm}$

Pada grafik, garis solid biru merupakan timer Embedded system. Sedangkan garis solid hijau merupakan timer Android. Sumbu X menyatakan waktu dalam millisecond (ms) dan sumbu Y menyatakan jumlah tag yang diuji. Setelah dilakukan 15 pengujian pembacaan tag pada kedua sistem, pengujian dengan jarak $15 \mathrm{~mm}$ pada sistem Android hasil yang didapatkan tidak terlalu baik. Beberapa tag tidak terdeteksi dan timer membaca dengan waktu yang sangat tinggi dalam beberapa momen, namun dominan lebih cepat dalam beberapa kali hasil pengujian Android lebih cepat dibandingkan Embedded system. Sedangkan pada Embedded system untuk timer tetap stabil dalam melakukan pengujian pada jarak $15 \mathrm{~mm}$.

Tingkat kestabilan yang ada pada Embedded system sangat baik ketika melakukan pembacaan tag. Pada pengujian pembacaan tag ketujuh pada sistem Android terjadi pembacaan tag yang sedikit lebih lambat (menembus angka 338 milisecond atau 0.3 second). Kemudian terlihat beberapa kali tag tidak terbaca pada sistem Android. Pada Embedded system selama dilakukan 15 kali pengujian pembacaan tag tidak mengalami masalah sensifitas dan tetap stabil menjalankan pembacan tag.

Selanjutnya dilakukan pengujian data terdistribusi normal sebagai syarat untuk mendapatkan metode uji statistik yang sesuai. Pengujian distribusi normal dilakukan berdasarkan waktu dari kedua perangkat (Android dan Embedded system). Perlu diketahui apabila setelah dilakukan pengujian, salah satu sampel atau keduanya tidak berdistribusi normal maka uji perbandingan dengan uji sample T-test tidak dapat dilakukan. Selanjutnya untuk metode uji perbandingan dilakukan dengan metode uji Mann Whitney [15,16,17]. Kemudian kedua sampel data diuji menggunakan aplikasi IBM SPSS

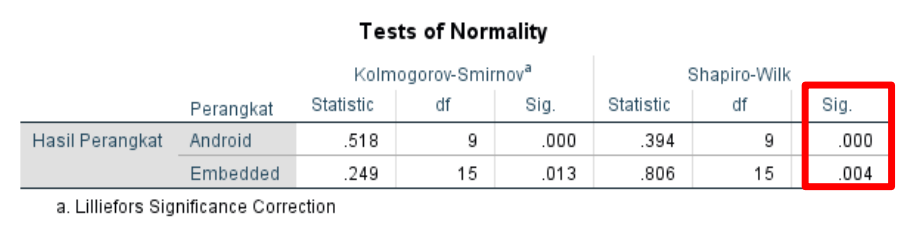

Gambar 11 Hasil uji normalitas pada jarak 15 mm

Berdasarkan hasil yang didapatkan, apabila salah satu atau kedua sampel sig. $<.005$ (lebih kecil dari .005) maka data tersebut tidak berdistribusi normal dan metode sample T-test tidak dapat dilakukan $[15,16,17]$. Selanjutnya metode uji yang dapat digunakan adalah metode uji Mann Whitney. 


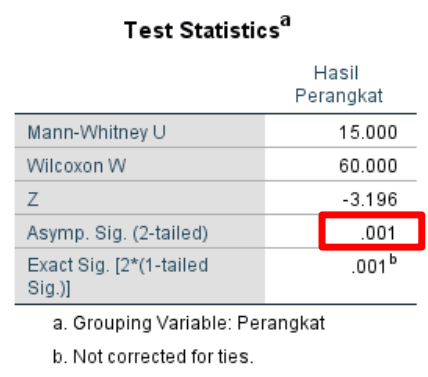

Gambar 12 Hasil uji Mann Whitney pada jarak 15 mm

Setelah didapatkan hasil akhir dari pengujian metode Mann Whitney. Hipotesis yang diajukan dalam penelitian ini adalah $\mathrm{Ha}=$ ada perbedaan signifikan dari kedua perangkat antara Android dan Embedded Sistem. Dasar pengambilan keputusan yang dijadikan acuan adalah sebagai berikut :

1. Jika nilai signifikansi atau Asymp. Sig. (2-tailed) lebih kecil dari probabilitas 0.05 maka hipotesis atau "Ha diterima".

2. Namun jika nilai signifikansi atau Asymp. Sig. (2-tailed) lebih besar dari probabilitas 0.05 maka hipotesis atau "Ha ditolak" [15,16,17].

Dari hasil yang didapatkan pada Asymp. Sig. (2-tailed) yaitu :

$$
\mathrm{Ha}=.001<0.05(1)
$$

Berdasarkan ouput dalam uji Mann Whitney diatas, diketahui bahwa nilai Asymp. Sig. (2-tailed) sebesar .001 lebih kecil < dari nilai probabilitas 0,05. Maka dapat disimpulkan bahwa "Ha diterima" bahwa terdapat perbedaan signifikan pada kedua perangkat berdasarkan jarak 15 $\mathrm{mm}$ dan waktu yang telah diuji. Selanjutnya dilakukan pengujian pada jarak $10 \mathrm{~mm}$ dengan melakukan pembacaan 15 tag NFC. Berikut ini adalah informasi waktu pada jarak $10 \mathrm{~mm}$ yang terbaca pada kedua perangkat (Android dan Embedded system) dapat dilihat pada Tabel 2.

Tabel 2 Pengujian pembacaan tag pada jarak $10 \mathrm{~mm}$

\begin{tabular}{|c|c|c|c|c|}
\hline $\begin{array}{c}\text { Jarak } \\
(\mathbf{m m})\end{array}$ & Tag & $\begin{array}{c}\text { Waktu } \\
\text { Android } \\
(\mathbf{m s})\end{array}$ & $\begin{array}{c}\text { Waktu } \\
\text { Embedded } \\
(\mathbf{m s})\end{array}$ \\
\hline 10 & & 1 & 29 & 176 \\
\hline 10 & & 2 & - & 175 \\
\hline 10 & & 3 & - & 176 \\
\hline 10 & & 4 & - & 176 \\
\hline 10 & & 5 & - & 175 \\
\hline 10 & & 6 & - & 175 \\
\hline 10 & & 7 & - & 175 \\
\hline 10 & & 8 & 31 & 175 \\
\hline 10 & & 9 & 28 & 176 \\
\hline 10 & & 10 & 29 & 175 \\
\hline 10 & & 11 & 28 & 176 \\
\hline 10 & & 12 & 28 & 176 \\
\hline 10 & & 13 & 28 & 175 \\
\hline 10 & & 14 & 29 & 176 \\
\hline 10 & & 15 & 28 & 175 \\
\hline
\end{tabular}

Dari hasil pengujian pada tabel dapat dilihat melalui grafik pada gambar 13. 


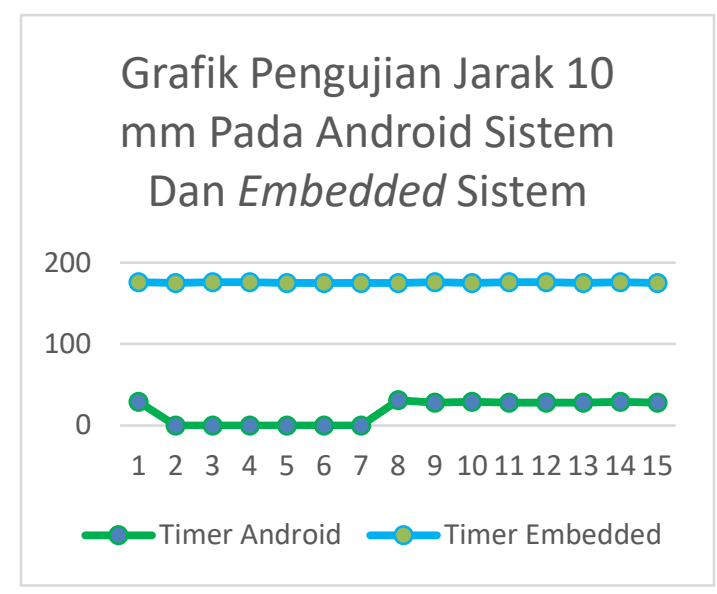

Gambar 13 Grafik waktu pengujian jarak $10 \mathrm{~mm}$

Berdasarkan grafik, setelah dilakukan 15 kali pengujian pembacaan tag NFC Android pada awalnya mampu membaca tag, namun kemudian beberapa tag tidak dapat terbaca. Dapat dilihat ketika dilakukan pengujian pembacaan pada tag kedua hingga ketujuh. Selanjutnya pada pembacaan tag kedelapan timer pada Android berjalan pada kisaran 29 - 28 milidetik. Pada Embedded system untuk timer berada di angka 100 milidetik atau 0.1 detik. Namun setelah beberapa kali dilakukan pengujian pembacaan tag NFC, hanya mempunyai kenaikan 0.001 milidetik, namun tidak terlalu jauh dengan nilai sebelumnya sehingga cukup stabil. Sama seperti pengujian sebelumnya, data kedua sampel harus diketahui apakah berdistribusi normal atau tidak. Kedua sampel data dari pembacaan tag NFC pada jarak $10 \mathrm{~mm}$ diuji menggunakan aplikasi IBM SPSS.

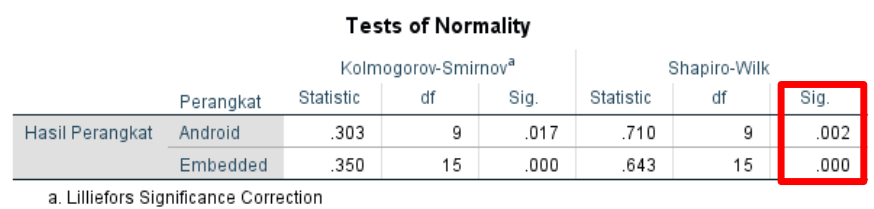

Gambar 14 Hasil uji normalitas pada jarak $10 \mathrm{~mm}$

Berdasarkan hasil diatas, apabila salah satu atau kedua sampel sig. lebih kecil $<0.005$ maka data tersebut tidak berdistribusi normal dan tidak dapat dilakukan pengujian dengan metode uji sample T-test $[15,16,17]$. Maka metode yang digunakan selanjutnya adalah metode uji Mann Whitney.

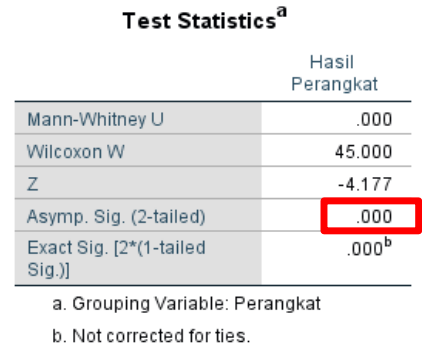

Gambar 15 Hasil uji Mann Whitney pada jarak 10 mm

Hipotesis yang diajukan dan menjadi acuan pada jarak $10 \mathrm{~mm}$ ini adalah $\mathrm{Ha}=$ ada perbedaan signifikan dari kedua perangkat antara Android dan Embedded system. Dari hasil yang didapatkan pada Asymp. Sig. (2-tailed) yaitu : 


$$
\mathrm{Ha}=.000<0.05(2)
$$

Berdasarkan ouput dalam uji Mann Whitney diatas diketahui bahwa nilai Asymp. Sig. (2-tailed) sebesar .000 lebih kecil < dari nilai probabilitas 0,05 . Oleh karena itu, sebagaimana dasar pengambilan keputusan uji Mann Whitney. Maka dapat disimpulkan bahwa "Ha diterima" bahwa terdapat perbedaan signifikan pada kedua perangkat berdasarkan jarak $10 \mathrm{~mm}$ dan waktu yang diuji. Pengujian pembacaan tag NFC selanjutnya dilakukan pada jarak $5 \mathrm{~mm}$ dengan melakukan pembacaan 15 tag NFC. Berikut ini adalah informasi waktu pada jarak $5 \mathrm{~mm}$ yang terbaca pada kedua perangkat (Android dan Embedded system) dapat dilihat pada Tabel 3.

Tabel 3 Pengujian pembacaan tag pada jarak $5 \mathrm{~mm}$

\begin{tabular}{|c|c|c|c|}
\hline $\begin{array}{c}\text { Jarak } \\
(\mathbf{m m})\end{array}$ & Tag & $\begin{array}{c}\text { Waktu } \\
\text { Android } \\
(\mathbf{m s})\end{array}$ & $\begin{array}{c}\text { Waktu } \\
\text { Embedded } \\
(\mathbf{m s})\end{array}$ \\
\hline 5 & 1 & 29 & 175 \\
\hline 5 & 2 & 27 & 175 \\
\hline 5 & 3 & 28 & 176 \\
\hline 5 & 4 & 29 & 176 \\
\hline 5 & 5 & 28 & 176 \\
\hline 5 & 6 & 28 & 175 \\
\hline 5 & 7 & 29 & 175 \\
\hline 5 & 8 & 29 & 176 \\
\hline 5 & 9 & 29 & 175 \\
\hline 5 & 10 & 29 & 175 \\
\hline 5 & 11 & 28 & 175 \\
\hline 5 & 12 & 28 & 175 \\
\hline 5 & 13 & 28 & 175 \\
\hline 5 & 14 & 28 & 177 \\
\hline 5 & 15 & 28 & 175 \\
\hline & & & \\
\hline
\end{tabular}

Dari hasil pengujian pada tabel dapat dilihat melalui grafik pada Gambar 16.

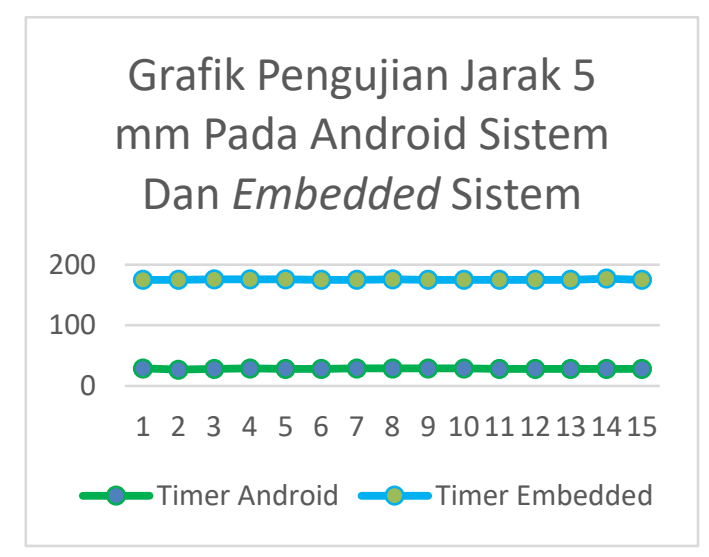

Gambar 16 Grafik waktu pengujian jarak 5 mm

Dapat dilihat pada kedua grafik setelah dilakukan pengujian membaca 15 tag pada jarak $5 \mathrm{~mm}$ sistem Android menjadi lebih stabil. Terlihat dari waktu yang ditunjukkan oleh timer. Android berjalan lebih stabil dalam pembacaan tag dengan jarak yang lebih dekat sekitar $5 \mathrm{~mm}$ dan benar-benar optimal dalam pembacaan tag NFC. Pada Embedded system terjadi kenaikan pada pembacaan tag namun kemudian tetap berjalan dengan stabil. Kenaikan nilai waktu pada timer terjadi pada pembacaan tag ketiga, keempat, kelima, dan kedelapan. Pada pengujian pembacaan tag keempat belas timer menjadi sedikit lebih lambat yaitu naik sebanyak 0.002 milidetik namun kemudian kembali berjalan pada nilai awal yaitu 175 milidetik ketika 
pembacaan tag terakhir dilakukan. Selanjutnya dilakukan pengujian untuk mengetahui data kedua sampel berdistribusi normal atau tidak. Kedua sampel data dari pembacaan tag NFC pada jarak $5 \mathrm{~mm}$ diuji menggunakan aplikasi IBM SPSS.

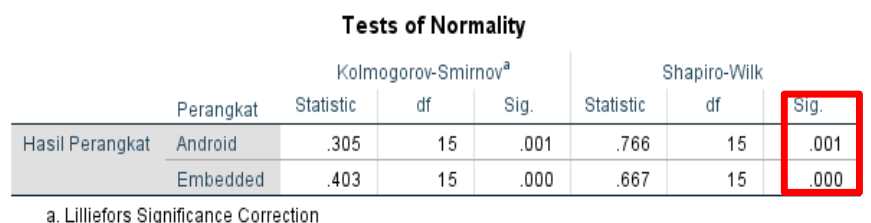

Gambar 17 Hasil uji normalitas pada jarak $5 \mathrm{~mm}$

Berdasarkan hasil diatas, apabila salah satu atau kedua sampel sig. $<0.005$ maka data tersebut tidak berdistribusi normal.

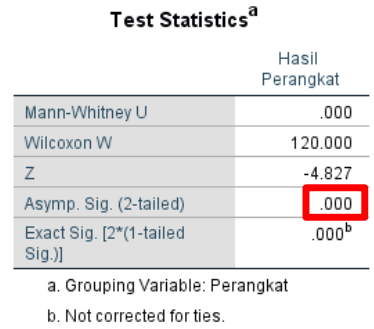

Gambar 18 Hasil uji Mann Whitney pada jarak $5 \mathrm{~mm}$

Hipotesis yang diajukan dan menjadi acuan dalam perhitungan jarak $5 \mathrm{~mm}$ masih sama seperti sebelumnya yaitu $\mathrm{Ha}=$ ada perbedaan signifikan dari kedua perangkat antara Android dan Embedded System berdasarkan hasil yang didapatkan pada Asymp. Sig. (2-tailed) yaitu :

$$
\mathrm{Ha}=.000<0.05(3)
$$

Berdasarkan hasil uji Mann Whitney diketahui bahwa nilai Asymp. Sig. (2-tailed) sebesar .000 lebih kecil dari < nilai probabilitas 0,05. Oleh karena itu, sebagaimana dasar pengambilan keputusan uji Mann Whitney maka dapat disimpulkan bahwa "Ha diterima" bahwa terdapat perbedaan signifikan pada kedua perangkat berdasarkan jarak $5 \mathrm{~mm}$ dan waktu yang diuji.

\section{KESIMPULAN DAN SARAN}

Setelah dilakukan penelitian, didapatkan hasil bahwa Android lebih cepat dibanding Embedded system yang didapatkan dari pengujian pada sampel jarak $15 \mathrm{~mm}, 10 \mathrm{~mm}$, dan 5 mm.dan terlihat hasil pada kedua perangkat terdapat perbedaan signifikan dalam melakukan pembacaan tag yang dibuktikan dengan menggunakan metode statistik uji Mann Whitney. Sehingga tujuan dari penelitian telah didapatkan dan terpenuhi. Selanjutnya penerapan untuk pembacaan tag NFC dapat dilakukan menggunakan perangkat Android untuk mendata setiap aset yang jumlahnya puluhan maupun ribuan. Pada Android terdapat pembacaan tag yang tidak terdeteksi dikarenakan terdapat aplikasi yang berjalan dibelakang layar. Android digunakan untuk menjalankan banyak aplikasi berjalan secara bersamaan namun proses pembacaan tag NFC berjalan lebih cepat dikarenakan menggunakan processor Exynos $7870 \mathrm{CPU} 2.2 \mathrm{GHz}$ Octa-core. Pada Embedded system hasil yang didapatkan cukup stabil karena merupakan perangkat dengan satu tujuan namun proses yang dilakukan relatif lebih lama dikarenakan menggunakan microcontroller ATmega2560 dengan clock speed $16 \mathrm{MHz}$. Kedepannya seiring dengan berjalannya waktu, processor dan microcontroller akan terus berkembang, sehingga hasil pengujian kinerja pembacaan tag NFC yang dilakukan pasti akan lebih baik lagi. 


\section{DAFTAR PUSTAKA}

[1]N. Shetty and H. Ragab-Hassen, "NFC-based asset management for medical equipment," 2015 IEEE 11th International Conference on Wireless and Mobile Computing, Networking and Communications (WiMob), Abu Dhabi, 2015, pp. 246-251.

[2]R. S. Basyari, S. M. Nasution and B. Dirgantara, "Implementation of host card emulation mode over Android smartphone as alternative ISO 14443A for Arduino NFC shield," 2015 International Conference on Control, Electronics, Renewable Energy and Communications (ICCEREC), Bandung, 2015, pp. 160-165.

[3]J. Dave, S. Gondaliya, B. Patel, A. Mascarenhas and M. Varghese, "M-commerce shopping using NFC," 2017 Third International Conference on Sensing, Signal Processing and Security (ICSSS), Chennai, India, 2017, pp. 203-213.

[4]S. M. Nasution, E. M. Husni and A. I. Wuryandari, "Prototype of train ticketing application using Near Field Communication (NFC) technology on Android device," 2012 International Conference on System Engineering and Technology (ICSET), Bandung, Indonesia, 2012, pp. $1-6$.

[5]Anne-Marie Lesas; Serge Miranda, "Developing NFC Applications with Android," in The Art and Science of NFC Programming, Wiley, 2017, pp.45-105.

[6] T. Hongthai and D. Thanapatay, "The development of encrypted near field communication data exchange format transmission in an NFC passive tag for checking the genuine product," 2017 14th International Conference on Electrical Engineering/Electronics, Computer, Telecommunications and Information Technology (ECTI-CON), Phuket, 2017, pp. 889-894.

[7]Coskun, V., Ozdenizci, B., and Ok, K. (2015). The Survey on Near Field Communication. Sensors, 15(6),13348-13405.

[8]A. Kamaraj, K. Radha, M. Priyanka and M. Punitha, "Intelligent transport system using integrated GPS optimized reader," 2016 Second International Conference on Science Technology Engineering and Management (ICONSTEM), Chennai, 2016, pp. 332-336.

[9]N. Meenakshi, M. Monish, K. J. Dikshit and S. Bharath, "Arduino Based Smart Fingerprint Authentication System," 2019 1st International Conference on Innovations in Information and Communication Technology (ICIICT), CHENNAI, India, 2019, pp. 1-7.

[10]T. Vince and O. Slavko, "Enhanced Centralized Access Control System," 2019 IEEE International Conference on Modern Electrical and Energy Systems (MEES), Kremenchuk, Ukraine, 2019, pp. 474-477.

[11]A. Zaher, J. Saersten, T. T. Nguyen and P. Häfliger, "Integrated electronic system for implantable sensory NFC tag," 2015 37th Annual International Conference of the IEEE Engineering in Medicine and Biology Society (EMBC), Milan, Italy, 2015, pp. 7119-7122.

[12] Hamzah, Muhammad L., and Astri A. Purwati. "Sistem Manajemen Inventori Komputer Menggunakan Near Field Communication Berbasis Android Studi Kasus di STIE Pelita Indonesia Pekanbaru." Costing, vol. 1, no. 1, 2017, pp. 95-104.

[13]Singgih, S., 2014, Panduan Lengkap SPSS Versi 2020 Edisi Revisi, Elex Media Komputindo, Jakarta.

[14]Statistik, C., 2020, Uji Mann-Whitney, https://statistikceria.blogspot.com/2014/06/ujimann-whitney.html, diakses tgl 17 November 2020.

[15]Sahid, R., 2020, Cara Uji Paired Sample T-Test dan Interpretasi dengan SPSS, https://www.spssindonesia.com/2016/08/cara-uji-paired-sample-t-test-dan.html, diakses tgl 21 December 2020.

[16]Sahid, R., 2020, Cara Uji Normalitas Shapiro- Wilk dengan SPSS Lengkap, https://www.spssindonesia.com/2015/05/cara-uji-normalitas-shapiro-wilk-dengan.html, diakses tgl 21 December 2020.

[17]Sahid, R., 2020, Contoh Kasus Uji Beda Mann Whitney Menggunakan SPSS, https://www.spssindonesia.com/2017/04/uji-mann-whitney-spss.html, diakses $\operatorname{tgl} 21$ December 2020. 